\title{
POLA KONSUMSI GARAM DENGAN KEJADIAN HIPERTENSI PADA LANSIA
}

\section{SALT CONSUMPTION PATTERN WITH HYPERTENSION IN ELDERLY}

\author{
Janu Purwono ${ }^{1}$, Rita Sari ${ }^{2}$, Ati Ratnasari ${ }^{3}$, Apri Budianto ${ }^{4}$, \\ ${ }^{1}$ Akademi Keperawatan Dharma wacana Metro \\ 2,3,4 Universitas Muhammdiyah Pringsewu Lampung \\ e-mail; janupurwono@gmail.com
}

\begin{abstract}
ABSTRAK
Hipertensi menurut data WHO tahun 2015 menunjukkan sekitar 1,13 miliar orang di dunia menderita hipertensi, yang berarti setiap 1 dari 3 orang di dunia terdiagnosis menderita hipertensi. Jumlah penderita hipertensi di dunia terus meningkat setiap tahunnya. Diperkirakan pada 2025 akan ada 1,5 miliar orang yang terkena hipertensi serta setiap tahun ada 9,4 juta orang meninggal akibat hipertensi dan komplikasi. Kejadian hipertensi lebih banyak diderita pada pralansia dan lansia dibandingkan dengan kelompok umur yang lebih muda. Tujuan penelitian untuk mengetahui hubungan pola konsumsi garam dengan kejadian hipertensi pada lansia di wilayah kerja Puskesmas Gadingrejo. Desain penelitian yang digunakan dalam penelitian ini adalah desain analitik dengan rancangan cross sectional. Analisis data menggunakan uji chi-square. Sampel dalam penelitian ini yaitu lansia sebagai peserta di Puskesmas Gadingrejo sebanyak 51 orang diambil dengan metode purposive sampling. Hasil penelitian didapatkan 54,9\% responden mengkonsumsi tinggi garam, 60,8\% responden mengalami hipertensi berat. Terdapat hubungan antara pola konsumsi garam dengan kejadian hipertensi pada lansia di Wilayah Puskesmas Gadingrejo dengan $\mathrm{P}$ value=0,010 dan nilai $\mathrm{OR}=5,704$. Disarankan pada Puskesmas Gadingrejo untuk melakukan pendeteksian dini hipertensi serta melakukan penyuluhan kepada masyarakat tentang pentingnya membatasi konsumsi garam.
\end{abstract}

Kata kunci : Pola konsumsi garam, Hipertensi, lansia

\begin{abstract}
Hypertension according to WHO data in 2015 showed that around 1.13 billion people in the world suffer from hypertension, which means that every 1 in 3 people in the world is diagnosed with hypertension. The number of people with hypertension in the world continues to increase every year. It is estimated that in 2025 there will be 1.5 billion people affected by hypertension and every year there are 9.4 million people die from hypertension and complications. The incidence of hypertension is more prevalent in pralansia and the elderly compared to younger age groups. The purpose of this study was to determine the relationship of salt consumption patterns with the incidence of hypertension in the elderly in the work area of Gadingrejo Public Health Center. The research design used in this study was analytic design with cross sectional design. Data analysis using chi-square test. The sample in this study is the elderly as participants in Puskesmas Gadingrejo as many as 51 people were taken by purposive sampling method. The results showed $54.9 \%$ of respondents consumed high salt, $60.8 \%$ of respondents had severe hypertension. There is a relationship between salt consumption patterns with the incidence of hypertension in the elderly in the Gadingrejo Community Health Center with P value $=0.010$ and $\mathrm{OR}=5.704$. It is recommended that Gadingrejo Health Center conduct early detection of hypertension and educate the public about the importance of limiting salt consumption.
\end{abstract}

Keywords: Salt consumption patterns, hypertension, elderly 


\section{PENDAHULUAN}

Hipertensi adalah isu kesehatan masyarakat yang penting dimana jarang menyebabkan gejala atau keterbatasan nyata pada kesehatan fungsional pasien. Hipertensi adalah faktor resiko utama pada penyakit jantung koroner, gagal jantung, serta stroke ${ }^{1} .$. Hipertensi di klasifikasikan menjadi dua, yaitu Hipertensi Primer (Esensial) dan Hipertensi sekunder ${ }^{2}$.

Kasus hipertensi menurut Data WHO 2015 menunjukkan sekitar 1,13 miliar orang di dunia menderita hipertensi, yang berarti setiap 1 dari 3 orang di dunia terdiagnosis menderita hipertensi, hanya $36,8 \%$ di antaranya yang minum obat. Jumlah penderita hipertensi di dunia terus meningkat setiap tahunnya. Diperkirakan pada 2025 akan ada 1,5 miliar orang yang terkena hipertensi serta setiap tahun ada 9,4 juta orang meninggal akibat hipertensi dan komplikasi ${ }^{3}$.

Prevalensi penderita Hipertensi di Indonesia menurut Badan Penelitian dan Pengembangan Kesehatan (BalitBanKes) melalui data hasil Riset Kesehatan Dasar (Riskesdas) 2018 saat ini sebanyak 34,1\% dimana mengalami kenaikan dari angka sebelumnya di tahun 2013 yaitu sebanyak $25,8 \%{ }^{4}$. Berdasarkan laporan Departemen Kesehatan Republik Indonesia kasus tertinggi hipertensi adalah provinsi Sulawesi Utara dengan presentasi sebanyak 13,2 \%. Provinsi Papua menjadi provinsi dengan penderita Hipertensi paling rendah di Indonesia yaitu sebanyak $4.4 \%$. Provinsi Lampung berada di urutan ke 21 dalam pravelensi hipertensi berdasarkan diagnosis dokter ${ }^{4}$.

Faktor penyebab terjadinya hipertensi adalah umur, jenis kelamin, riwayat keluarga, genetik (faktor resiko yang tidak dapat diubah/dikontrol), kebiasaan merokok, obesitas, kurang aktivitas fisik, stress, penggunaan estrogen dan salah satunya yang dapat menyebabkan terjadinya hipertensi adalah pola konsumsi garam dengan intake berlebihan ${ }^{4}$.Penyebab hipertensi diantaranya adalah konsumsi makanan asin, kafein, konsumsi mono sodium glutamat (vetsin, kecap, pasta udang). 5.

Di Indonesia konsumsi garam atau banyaknya kandungan natrium dalam makanan yang dikonsumsi oleh masyarakat merupakan salah satu penyebab hipertensi ${ }^{6}$. Natrium yang diserap ke dalam pembuluh darah yang berasal dari konsumsi garam yang tinggi mengakibatkan adanya retensi air, sehingga volume darah meningkat. Asupan natrium yang tinggi akan menyebabkan pengeluaran berlebihan dari hormon natrioretik yang secara tidak langsung akan meningkatkan tekanan darah ${ }^{7}$.

Penelitian yang telah dilakukan oleh beberapa peneliti mengatakan terdapat hubungan yang signifikan antara asupan 
natrium dengan kejadian hipertensi seperti penggunaan garam berlebihan ${ }^{9,10,11,12}$.

Data yang didapat dari Puskesmas Gadingrejo Kabupaten Pringsewu bahwa terdapat 107 lansia yang menderita hipertensi primer dan setiap tahunnya selalu meningkat. Penderita hipertensi tahun 2018 termasuk 5 besar penyakit terbanyak di Puskesmas Gadingrejo yaitu $2,11 \%$ setelah comommon cold, gastritis, influenza dan dermatitis kontak.Dimana dengan pra surveyyang dilakukan oleh peneliti di Puskesmas Gadingrejo terhadap 10 pasien hipertensi diantaranya mengalami kekambuhan hipertensi dikarenakan makan-makanan asin dengan penggunaan garam berlebihan seperti ikan asin.

Berdasarkan uraian diatas maka peneliti tertarik untuk melakukan penelitian tentang hubungan Pola Konsumsi Garam Dengan Kejadian Hipertensi Pada Lansia Di Wilayah Kerja Puskesmas Gadingrejo.

\section{METODE}

Penelitian ini menggunakan jenis penelitian analitik korelasi dengan variabel independen pola konsumsi garam, dengan variabel dependen kejadian hipertensi. Desain penelitian menggunkan pendekatan cross sectional. Penentuan sampel dalam penelitian ini menggunakan tekhnik purposive sampling.Jumlah sampel dalam penelitian ini adalah 51 responden. Lembar instrumen yang akan digunakan berupa kuesioner. Uji Statistik yang digunakan adalah uji chi square.

\section{HASIL}

Usia

Tabel 1

Usia responden, $\mathrm{n}=51$

\begin{tabular}{cccc}
\hline Variabel & Mean & Median & Min-max \\
\hline Usia & 67,04 & 66,00 & $60-80$ \\
\hline
\end{tabular}

Berdasarkan tabel 1 diketahui bahwa ratarata usia responden Puskesmas Gadingrejo adalah 67,04 tahun, nilai median 66.00, usia termuda responden dalam penelitian ini adalah 60 tahun dan usia tertua responden adalah 80 tahun.

\section{Jenis Kelamin}

Tabel 2

Jenis Kelamin Responden, $\mathbf{n = 5 1}$

\begin{tabular}{|c|c|c|}
\hline $\begin{array}{c}\text { Jenis } \\
\text { Kelamin }\end{array}$ & Frekuensi & Presentase $(\%)$ \\
\hline Perempuan & 35 & 68,6 \\
\hline Laki-laki & 16 & 31,4 \\
\hline \multicolumn{2}{|c|}{ Total } & $100 \%$ \\
\hline
\end{tabular}

Berdasarkan Tabel 2 dapat diketahui bahwa dari 51 lansia yang menjadi sampel penelitian di Puskesmas Gadingrejo tahun 2019 didapatkan sebanyak 35 (68,6\%) lansia berjenis kelamin perempuan dan 16 $(31,49 \%)$ lansia yang berjenis kelamin laki-laki. 
Pola Konsumsi Garam

Tabel 3

Pola Konsumsi Garam Responden , $n=51$

\begin{tabular}{ccc}
\hline Pemakaian Garam & Frekuensi & Presentase (\%) \\
\hline Rendah garam & 23 & 45,1 \\
\hline Tinggi Garam & 28 & 54,9 \\
\hline Total & 51 & $100 \%$ \\
\hline
\end{tabular}

Berdasarkan Tabel 3 dapat diketahui bahwa dari 51 lansia yang menjadi sampel penelitian di Puskesmas Gadingrejo tahun 2019 didapatkan sebanyak 23 (45,1\%) lansia yang mengkonsumsi rendah garam dan 28 (54,9\%) lansia yang mengkonsumsi tinggi garam.

\section{Hipertensi Pada Lansia}

Tabel 4

Pola Kejadian Hipertensi Responden, $\mathbf{n = 5 1}$

\begin{tabular}{ccc}
\hline Hipertensi & Frekuensi & Presentase (\%) \\
\hline Pra Hipertensi & 20 & 39,2 \\
\hline Hipertensi & 31 & 60,8 \\
\hline Total & 51 & $100 \%$ \\
\hline
\end{tabular}

Berdasarkan Tabel 4 dapat diketahui bahwa dari 51 lansia yang menjadi sampel penelitian di Puskesmas Gadingrejo tahun 2019 didapatkan sebanyak 20 (39,12\%) lansia menderita pra hipertensi dan $31(60,8 \%)$ lansia yang menderita penyakit hipertens

\section{Analisa Bivariat}

Tabel 5

Hubungan Pola Konsumsi Garam Terhadap Kejadian Hipertensi Pada Lansia , $\mathbf{n = 5 1}$

\begin{tabular}{|c|c|c|c|c|c|c|c|c|}
\hline \multirow{3}{*}{$\begin{array}{c}\text { Konsumsi } \\
\text { Garam }\end{array}$} & \multicolumn{4}{|c|}{ Hipertensi } & \multirow{2}{*}{\multicolumn{2}{|c|}{ Total }} & \multirow{3}{*}{ P.value } & \multirow[b]{2}{*}{ OR } \\
\hline & \multicolumn{2}{|c|}{$\begin{array}{c}\text { Pra } \\
\text { Hipertensi }\end{array}$} & \multicolumn{2}{|c|}{ Hipertensi } & & & & \\
\hline & $\mathbf{N}$ & $\%$ & $\mathbf{N}$ & $\%$ & $\mathbf{N}$ & $\%$ & & \multirow{4}{*}{5.704} \\
\hline $\begin{array}{l}\text { Rendah } \\
\text { Garam }\end{array}$ & 14 & 60.9 & 9 & 39,1 & 23 & 100 & \multirow[t]{3}{*}{0.010} & \\
\hline $\begin{array}{l}\text { Tinggi } \\
\text { Garam }\end{array}$ & 6 & 21,4 & 22 & 78,6 & 28 & 100 & & \\
\hline Total & 20 & 39,2 & 31 & 60,8 & 51 & 100 & & \\
\hline
\end{tabular}


Berdasarkan Tabel 5 diketahui bahwa terdapat 23 lansia yang mengkonsumsi rendah garam,didapatkan sebanyak 16 $(60,9 \%)$ lansia yang menderita pra hipertensi dan 9 (39,1\%) lansia yang menderita hipertensi. Kemudian diketahui dari 28 lansia yang mengkonsumsi tinggi garam didapatkan $6 \quad(21,4 \%)$ yang mengalami pra hipertensi dan $22(78,6 \%)$ lansia mengalami hipertensi. Hasil uji chi square dan uj statistic $\mathrm{P}$ value $=0.010$ lebih kecil dibandingkan $\propto(0.010<0,05)$ maka Ho ditolak dan Ha diterima, sehingga terdapat hubungan yang bermakna antara pola konsumsi garam terhadap kejadian hipertensi pada lansia di Puskesmas Gadingrejo tahun 2019, dengan nilai odd ratio $(\mathrm{OR}=5.704)$ yang artinya bahwa responden yang mengkonsumsi tinggi garam memiliki resiko 5.704 kali lebih besar menghalami hipertensi dibandingkan dengan responden yang mengkonsumsi rendah garam.

\section{PEMBAHASAN}

\section{Usia}

Hasil penelitian ini sejalan dengan penelitian yang dilakukan oleh Siregar, M. A., \& Lubis, Z. tentang hubungan asupan natrium dengan kejadian hipertensi di UPT Pelayanan Sosial Lanjut Usia Binjai menunjukan bahwa sebagain besar responden hipertensi berusia berusia 60-74 tahun $^{13}$.
Menurut Rahayu peningkatan kejadian hipertensi yang dipengaruhi oleh bertambahnya umur terjadi secara alami sebagai proses menua dan didukung oleh beberapa faktor eksternal. Hal ini berkaitan dengan perubahan struktur dan fungsi kardiovaskuler. Seiring dengan bertambahnya umur, dinding vertikel kiri dan kutub jantung menebal serta elastisitas pembuluh darah menurun. Atherosclorosis meningkat, terutama dengan individu yang mempunyai gaya hidup tidak sehat. Kondisi inilah yang menyebabkan peningkatan tekanan darah sistolikmaupun distolik berdampak pada peningkatan tekanan darah ${ }^{14}$.

Menurut pendapat peneliti lanjut usia (lansia) sangan rentan terkena penyakit hipertensi. Semakin menua usia responden semakin menurun pola kerja dan fungsi jantung. Dengan bertambahnya umur, maka tekanan darah juga akan meningkat, dinding arteri akan mengalami penebalan oleh karena adanya penumpukan zat kolagen pada lapisan otot, sehingga pembuluh darah akan berangsur-angsur menyempit dan menjadi kaku.Peningkatan umur akan menyebabkan beberapa perubahan fisiologis, pada usia lanjut terjadi peningkatan resistensi perifer dan aktivitas simpatik.

\section{Jenis Kelamin}

Hasil penelitian ini sejalan dengan penelitian yang dilakukan oleh Susanti, M. 
R., Muwakhidah, S., \& Wahyuni, S tentang hubungan asupan natrium dan kalium dengan tekanan darah pada lansia di Kelurahan Panjang. Hasil penelitian ini menunjukan bahwa sebagian besar berjenis kelamin perempuan yaitu sebanyak(92,5\%).Pada umumnya risiko tekanan darah tinggi lebih tinggi pada lakilaki daripada wanita, namun memasuki usia>45 tahun wanita mempunyai risiko lebih tinggi dikarenakan wanita mulai memasuki usia menopouse. Hal ini disebabkan terjadi penurunan produksi estrogen yang akan berdampak pada kardiovaskuler dimana terjadi penurunan elastisitas pembuluh darah ${ }^{15}$.

Menurut Irza, S. pada dasarnya prevalensi terjadinya hipertensi pada pria sama dengan wanita. Pada wanita premenopouse wanita mulai kehilangan sedikit demi sedikit hormon estrogen yang selama ini melindungi pembuluh darah dari kerusakan. Proses ini akan terus berlanjut dimana hormon estrogen tersebut berubah kuantitasnya sesuai dengan umur wanita secara alami, yang umumnya mulai terjadi pada wanita 45-55 tahun. Oleh karena itu ketika wanita sudah menopouse akan sama beresikonya untuk terkena penyakit hipertensi ${ }^{16}$.

Menurut pendapat peneliti jenis kelamin memiliki pengaruh terhadap timbulnya penyakit hipertensi. Laki-laki ataupun perempuan memiliki tingkat perbedaan yang tidak terlalu jauh untuk terserang hiperensi. Hal ini dikarenakan `oleh bebrapa factor yang memungkinkan, jika laki-laki lebih kepada gaya hidup seperti halnya kebisaan merokok, stress,konsumsi kopi dan makanan yang tidak terkontrol. Sedangkan pada wanita lansia akibat pengaruh dari menopause yang mengakibatkan perubahan hormone estrogen yang berfungsi melindungi pembuluh darah dari kerusakan.

\section{Pola Konsumsi Garam}

Hasil penelitian ini didukung oleh penelitian Devi Dewi, S. mengatakan dalam penelitianya mengenai hubungan tingkat konsumsi garam terhadap kejadian hipertensi di Nagari Lunang Barat wilayah kerja Puskesmas Tanjung Beringin Kecamatan Lunang Kabupaten Pesisir Selatan menunjukkan bahwa responden yang mengkonsumsi tinggi garam lebih banyak menderita hipertensi dibanding dengan responden yang kurang mengkonsumsi garam ${ }^{7}$.

Penelitian tentang asupan garam juga dilakukan oleh Lin dengan menunjukkan hasil bahwa asupan garam harian dari mayoritas warga yang tinggal di Ningbo melebihi DRI ( 6 g/d) di Tiongkok meningkatkan risiko hipertensi. Selain itu, intervensi kesehatan masyarakat dari pembatasan garam diperlukan untuk itu pencegahan dan pengendalian epidemi 
penyakit kronis yang sedang berlangsung ${ }^{17}$.

Studi di India menunjukkan asupan garam lebih tinggi dari yang direkomendasikan . Ada kebutuhan mendesak untuk mengatasi masalah konsumsi garam tinggi dan lemak jenuh. Strategi gizi untuk mengurangi asupan garam, lemak jenuh dan menyeimbangkan nutrisi energi harus segera diterapkan pada pasien hipertensi dan dislipidemia ${ }^{18}$.

Penelitian di Somalia menunjukkan tentang pengukuran asupan garam yang akurat adalah langkah mendasar dalam pengembangan dan pemantauan program nasional untuk mengurangi asupan garam pada masyarakat. Program pengukuran garam diperlukan untuk memastikan bahwa negara-negara untuk mencapai target global pengurangan $30 \%$ dalam asupan garam di masyarakat pada tahun 2025, yang diproyeksikan untuk menyelamatkan sekitar 2 juta jiwa per tahun serta jutaan dolar dalam pengeluaran perawatan Kesehatan ${ }^{19}$.

Penelitian di Yordan juga menunjukkan bahwa asupan natrium tinggi dan kalium rendah memiliki efek buruk sinergis pada kesehatan masyarakat yang saat ini tidak ditangani di Yordania. Warga negara Yordania saat ini mengkonsumsi natrium tinggi dan diet rendah kalium dan sebagian besar tidak menyadari dampak negatifnya terhadap kesehatan mereka. Oleh karena itu, sangat penting bagi penyedia layanan kesehatan untuk campur tangan dan mengadopsi strategi jangka panjang untuk mengontrol asupan garam untuk mengurangi efek negatifnya di Yordania dan di tempat lain ${ }^{20}$.

Penelitian di Iran meunjukkan pola asupan garam yang berbeda diamati antara pria dan wanita. Secara umum, jumlah garam yang diambil oleh pasien hipertensi lebih tinggi dari tunjangan yang direkomendasikan. Baik pria maupun wanita menambahkan jumlah tambahan garam ke makanan, wanita saat menyiapkan makanan dan pria di meja. Tingkat asupan garam baik selama menyiapkan dan makan makanan dapat dikaitkan dengan pekerjaan (pengangguran), tingkat tekanan darah (sistolik / diastolik $\geq 140$ / 90), jenis kelamin (pria), usia (54-59), dan juga pengetahuan pasien (umum) ${ }^{21}$.

Konsumsi garam atau banyaknya kandungan natrium dalam makanan yang dikonsumsi oleh masyarakat merupakan salah satu penyebab hipertensi. Natrium yang diserap ke dalam pembuluh darah yang berasal dari konsumsi garam yang tinggi mengakibatkan adanya retensi air, sehingga volume darah meningkat. Hal ini 
yang mengakibatkan naiknya tekanan darah. Asupan natrium yang tinggi akan menyebabkan pengeluaran berlebihan dari hormon natriouretik yang secara tidak langsung akan meningkatkan tekanan $\operatorname{darah}^{22}$.

Menurut peneliti pola kosumsi garam terhadap responden sangat berpengaruh terhadap terjadinya hipertensi.Garam memiliki hubungan yang sebanding dengan timbulnya hipertensi. Semakin banyak jumlah garam dalam tubuh, maka akan terjadi peningkatan volume plasma, curah jantung, dan tekanan darah. Disamping itu, konsumsi garam dalam jumlah yang tinggi dapat mengecilkan diameter arteri, sehingga jantung harus memompa lebih keras untuk mendorong volume darah yang meningkat melalui ruang semangkin sempit akibatnya dapat menyebabkan hipertensi.

\section{Kejadian hipertensi pada Lansia}

Penelitian menunjukkan ada hubungan antara konsumsi makanan asin dengan kejadian hipertensi pada lansia di Puskesmas Pattingalloang Kota Makassar $^{22}$. Selain itu juga terdapat hubungan yang signifikan antara jenis kelamin dengan kejadian hipertensi pada lansia di Wilayah Kerja Puskesmas Lakbok Kabupaten Ciamis karena nilai X2hitung > $\mathrm{X} 2$ tabel $(11,445>7,185)$ dan nilai $\alpha>\rho$ value $(0,05>0,01)^{23}$.
Peneliti lain mengatakan terdapat hubungan yang signifikan antara kejadian stres dengan penyakit hipertensi pada lansia dengan menggunakan Fisher's Exact Test $(p=0,000)^{24}$. Selain itu ada hubungan antara aktivitas fisik ( $\mathrm{p}=0,024 \mathrm{OR}=3,596)$, asupan lemak ( $\mathrm{p}=0,008 \mathrm{OR}=4,364)$, dan asupan natrium $\quad(p=0,001 \quad \mathrm{OR}=6,103)$ dengan kejadian hipertensi. Analisis multivariat menunjukkan asupan natrium $(\mathrm{OR} \operatorname{Exp}(B)=4,627)$ sebagai faktor resiko yang paling berhubungan dengan kejadian hipertensi ${ }^{25}$.

Peneliti lain juga mengungkapkan terdapat hubungan yang bermakna antara genetik $(\mathrm{p}$ $=0,019 ; \mathrm{RP}=1,417 ; \mathrm{IK} 95 \%$ 1,069 sampai $1,877)$, olah raga $(\mathrm{p}=0,017 ; \mathrm{RP}=1,424$; IK 95\% 1,069 sampai 1,895), dan tingkat stress ( $\mathrm{p}<0,0001 ; \mathrm{RP}=2,043 ; \mathrm{IK} 95 \%$ 1,184 sampai 2,141) dengan kejadian hipertensi. Sedangkan jenis kelamin, obesitas, merokok, dan konsumsi alkohol tidak terdapat hubungan yang bermakna dengan kejadian hipertensi ${ }^{26}$.

Pada variabel tingkat konsumsi terdapat 3 (tiga) variabel yang berhubungan secara signifikan dengan kejadian hipertensi yaitu variabel lemak $(\mathrm{p}=0,010)$, natrium $(\mathrm{p}=$ $0,004)$, serat $(\mathrm{p}=0,000)$, sedangkan variabel karbohidrat tidalk berhubungan secara signifikan (nilai p $(0,599)>\alpha(0,05)$ ) dengan kejadian hipertensi ${ }^{27}$. 
Menurut pendapat peneliti kejadian hipertensi dipengaruhi oleh banyak faktor, antara lain aktifitas fisik yang kurang, stres, riwayat keluarga, kebiasaan merokok, tingginya konsumsi makanan yang mengandung lemak hewani, kurangnya konsumsi serat, dan tinggi konsumsi natrium. Dalam berbagai hasil studi diketahui faktor yang memicu terjadinya hipertensi yaitu riwayat keluarga, jenis kelamin, usia, pola konsumsi makanan yang mengandung natrium, tinggi konsumsi makanan yang mengandung lemak, perilaku merokok, obesitas, dan kurangnya aktivitas fisik. Kejadian hipertensi pada lansia di Puskesmas Gadingrejo ini disebabkan selain oleh faktor pola konsumsi garam yang tinggi juga dipengaruhi oleh faktor lain seperti adanya riwayat hipertensi sebelumnya, pola hidup yang tidak sehat , kebiasaan merokok, stres dan faktor lainya yang mampu memicu terdjadinya hipertensi.

\section{Hubungan Pola Konsumsi Garam Terhadap Kejadian Hipertensi Pada Lansia}

Kebiasaan asupan garam pada lansia dengan hipertensi sebagian besar termasuk dalam kategori sering, kebiasaan konsumsi makanan berlemak lansia hipertensi sebagian besar termasuk dalam kategori sering, kebiasaan merokok lansia hipertensi sebagian besar adalah bukan perokok, kebiasaan olahraga lansia hipertensi sebagian besar termasuk dalam kategori kurang baik. Keempat faktor yang diteliti berhubungan dengan kejadian hipertensi pada lansia di Pusling Desa Klumpit UPT Puskesmas Gribig ${ }^{28 .}$.

Peneliti lain mengatakan bahwa konsumsi lemak dan alkohol yang tinggi adalah faktor risiko yang mempengaruhi kejadian hipertensi di kalangan lansia di Kota Tomohon $^{29}$. Penelitian lain menunjukkan korelasi antara aktivitas olahraga $((\mathrm{p}=$ 0,021), asupan natrium ( $\mathrm{p}=0,020)$, obesitas $(\mathrm{p}=0,001)$, pasien dengan riwayat hipertensi $(\mathrm{p}=0,090)$, merokok $(\mathrm{p}=$ 0,092) dengan kejadian hipertensi pada lansia, daripada, kegiatan olahraga dan obesitas adalah faktor yang paling terkait dengan kejadian hipertensi pada lansia ${ }^{30}$.

Asupan garam yang tinggi telah terbukti meningkatkan tidak hanya tekanan darah tetapi juga risiko stroke, hipertrofi ventrikel kiri, dan proteinuria. Efek buruk yang terkait dengan pengurangan asupan garam. Pengurangan asupan garam diet dapat menunda atau mencegah timbulnya terapi antihipertensi, dapat memfasilitasi pengurangan tekanan darah pada pasien hipertensi yang menerima terapi medis, dan dapat mewakili mediator hemat biaya sederhana untuk mengurangi morbiditas dan mortalitas kardiovaskular ${ }^{31}$. Penelitian lain juga menunjukkan bahwa pengetahuan 
$(\mathrm{p}$-value $=0,000)$, stres $(\mathrm{p}$-value $=0,000)$ dan asupan garam $(\mathrm{p}$-value $=0,012)$ dikaitkan dengan kejadian kejadian hipertensi pada wanita lansia di rumah sakit umum rawat jalan Bahteramas Provinsi Sulawesi Tenggara . Oleh karena itu perlu menambah pengetahuan melalui penyuluhan tentang hipertensi bersamaan dengan risiko stres dan kelebihan asupan garam $^{32}$.

Menurut pendapat peneliti garam merupakan faktor yang cukup berpengaruh untuk timbulnya hipertesi. Konsumsi garam yang berlebih menyebabkan konsentrasi natrium didalam cairan ekstraseluler meningkat. Untuk menormalkannya cairan intraseluler ditarik keluar, sehingga volume cairan ekstraseluler meningkat. Meningkatnya volume cairan ekstraseluler tersebut menyebabkan meningkatnya volume darah, sehingga berdampak kepada timbulnya hipertensi. Hipertensi pada lansia dipengaruhi oleh asupan garam, stress, pegetahuan, konsumsi lemak, alcohol berlebihan, obesiatas. Efek pemasukan garam yang berlebihan pada lansia dapat menyebabkan stroke, hipertrofi ventrikel kiri, dan proteinuria.

\section{KESIMPULAN}

Terdapat hubungan antara pola konsumsi garam dengan kejadian hipertensi pada lansia di wilayah kerja Puskesmas Gadingrejo.

\section{SARAN}

Bagi peneliti selanjutnya hasil penelitian ini diharapkan dapat dijadikan sebagai bahan referensi dan menambah pengetahuan bagi peneliti yang akan melakukan penelitian tentang hipertensi pada lansia dengan variabel yang lebih kompleks, untuk menghitung recall garam dalam gram dibagi dengan jumlah keluarga yang tinggal dengan klien.

\section{DAFTAR PUSTAKA}

1. LeMone, P., Burke, K., M., \& Bauldoff, G. (2018). Buku ajar Keperawatan Medikal Bedah, Gangguan Kardiovaskuler. Diagnosis Keperawatan Nanda Pilihan, NIC NOC. Alih Bahasa : Subekti, B.N. Jakarta : EGC

2. Udjianti, W. J. (2010). Keperawatan Kardiovaskuler. Jakarta : Salemba Medika

3. DepKes, RI. (2019). Hipertensi Membunuh Diam-Diam, Ketahui Tekanan Darah Anda. Kementrian Kesehatan Republik Indonesia. $22 \mathrm{Mei}$ 2019.

http://www.depkes.go.id/article/view/1 $\underline{\text { 8051600004/hipertensi-membunuh- }}$ diam-diam-ketahui-tekanan-darahanda.html

4. RisKesDas .(2018). Kementrian Kesehatan, Badan Penelitian Dan Pengembangan Kesehatan, Hasil Utama RisKesDas 2018. 14 Mei 2019. http://www.depkes.go.id/resources/do wnload/info-terkini/hasil-riskesdas2018.pdf 
5. Indrawati, L., Werdhasari, A., \& Kristanto, A. Y. (2009). Hubungan pola kebiasaan konsumsi makanan masyarakat miskin dengan kejadian hipertensi di Indonesia. Media Penelitian dan Pengembangan Kesehatan, 19(4).

6. Depkes RI. 2013. Riset Kesehatan Dasar. Jakarta: Menteri Kesehatan RI

7. Devi Dewi, S. (2014). Hubungan Tingkat Konsumsi Garam Terhadap Kejadian Hipertensi Di Nagari Lunang Barat Wilayah Kerja Puskesmas Tanjung Beringin Kecamatan Lunang Kabupaten Pesisir Selatan Tahun 2014 (Doctoral dissertation, Universitas Andalas).

8. Wahyuni, dkk. 2014. Hubungan Asupan Natrium Dengan Kejadian Hipertensi Di Upt Pelayanan Sosial Lanjut Usia Binjai. Jurnal: Kampus USU Medan

9. Zainuddin, A \& Yunawati, I. 2012.Asupan Natrium Dan Lemak Berhubungan Dengan Kejadian Hipertensi Pada Lansia Di Wilayah Poasia Kota Kendari. Jurnal: Fakultas Kesehatan Masyarakat, Universitas Halu Oleo

10. Rawasiah.2015. Hubungan Faktor Konsumsi Makanan Dengan Kejadian Hipertensi Pada Lansia Di Puskesmas Pattingalloang. Fakultas Kesehatan Masyarakat Universitas Hasanuddin

11. Fitri, Y dkk.2018.Asupan Natrium Dan Kalium Sebagai Faktor Penyebab Hipertensi Pada Usia Lanjut. Jurnal AcTion: Aceh Nutrition Journal

12. Wahyuni, E dkk (2014), Zainuddin A \& Yunawati I (2012), dan Rawasiah dkk (2015), Fitri dkk (2018)

13. Siregar, M. A., \& Lubis, Z. (2015). Hubungan Asupan Natrium Dengan Kejadian Hipertensi Di Upt Pelayanan Sosial Lanjut Usia Binjai Tahun 2014. Gizi, Kesehatan Reproduksi dan Epidemiologi, 1(1).
14. Rahayu, H. (2012). Faktor risiko hipertensi pada masyarakat RW 01 Srengseng Sawah, Kecamatan Jagakarsa Kota Jakarta Selatan. Depok: $\quad$ Universitas Indonesia.

15. Susanti, M. R., Muwakhidah, S., \& Wahyuni, S. (2017). Hubungan Asupan Natrium dan Kalium dengan Tekanan Darah pada Lansia di Kelurahan Pajang (Doctoral dissertation, Universitas Muhammadiyah Surakarta).

16. Irza, S. (2009). Analisis Faktor Risiko Hipertensi Pada Masyarakat Nagari Bungo Tanjung, Sumatera Barat.

17. Lin, Y., Mei, Q., Qian, X., \& He, T. (2020). Salt consumption and the risk of chronic diseases among Chinese adults in Ningbo city. Nutrition Journal, 19(1), 9.

18. Kumbla, D., Dharmalingam, M., Dalvi, K., Ray, S., Shah, M. K., Gupta, S., ... \& Murugan, M. (2016). A study of salt and fat consumption pattern in regional Indian diet among hypertensive and dyslipidemic PaTients-SCRIPT study. $J$ Assoc Physicians India, 64(12), 47-54.

19. Webster, J., Su'a, S. A. F., Ieremia, M., Bompoint, S., Johnson, C., Faeamani, G., ... \& Viali, S. (2016). Salt intakes, knowledge, and behavior in Samoa: monitoring saltconsumption patterns through the world health organization's surveillance of noncommunicable disease risk factors (STEPS). The Journal of Clinical Hypertension, 18(9), 884-891.

20. Alawwa, I., Dagash, R., Saleh, A., \& Ahmad, A. (2018). Dietary salt consumption and the knowledge, attitudes and behavior of healthy adults: a cross-sectional study from Jordan. Libyan Journal of Medicine, 13(1).

21. Widanti. (2013). Keamanan Pangan Jilid 2. Bogor: Mbrio Press

22. Rawasiah, A. B., \& Wahiduddin, R. (2014). Hubungan Faktor Konsumsi Makanan dengan Kejadian Hipertensi 
Pada Lansia di Puskesmas Pattingallong. Makasar: Bagian Epidemiologi Fakultas Kesehatan Masyarakat Universitas Hasanuddin.

23. Kusumawaty, J., Hidayat, N., \& Ginanjar, E. (2016). Hubungan Jenis Kelamin dengan Intensitas Hipertensi pada Lansia di Wilayah Kerja Puskesmas Lakbok Kabupaten Ciamis. Mutiara Medika: Jurnal Kedokteran dan Kesehatan, 16(2), 46-51.

24. Seke, P. A., Bidjuni, H., \& Lolong, J. (2016). Hubungan kejadian stres dengan penyakit hipertensi pada lansia di balai penyantunan lanjut usia senjah cerah kecamatan mapanget kota manado. Jurnal Keperawatan, 4(2).

25. Mahmudah, S., Maryusman, T., Arini, F. A., \& Malkan, I. (2015). Hubungan gaya hidup dan pola makan dengan kejadian hipertensi pada lansia di Kelurahan Sawangan Baru Kota Depok tahun 2015. Biomedika, 7(2).

26. Arifin, M. H. B. M., Weta, I. W., \& Ratnawati, N. L. K. A. (2016). Faktor-faktor yang berhubungan dengan kejadian hipertensi pada kelompok lanjut usia di wilayah kerja UPT Puskesmas Petang I Kabupaten Badung tahun 2016. E-Jurnal Medika, 5(7), 2303-1395.

27. Widyaningrum, S. (2012). Hubungan antara konsumsi makanan dengan kejadian hipertensi pada lansia.
28. Arif, D., Rusnoto, R., \& Hartinah, D. (2013). Faktor-Faktor Yang Berhubungan Dengan Kejadian Hipertensi Pada Lansia Di Pusling Desa Klumpit Upt Puskesmas Gribig Kabupaten Kudus. Jurnal Ilmu Keperawatan dan Kebidanan, 4(2).

29. Malonda, N. S. H., Dinarti, L. K., \& Pangastuti, R. (2012). Pola makan dan konsumsi alkohol sebagai faktor risiko hipertensi pada lansia. Jurnal Gizi Klinik Indonesia, 8(4), 202-212.

30. Fitrina, Y. (2014). Faktor-Faktor Yang Berhubungan Dengan Kejadian Hipertensi Pada Usia Lanjut Di Wilayah Kerja Puskesmas Kebun Sikolos Kecamatan Padang Panjang Barat Tahun 2014. 'AFIYAH, 1(2).

31. Frisoli, T. M., Schmieder, R. E., Grodzicki, T., \& Messerli, F. H. (2012). Salt and hypertension: is salt dietary reduction worth the effort?. The American journal of medicine, 125(5), 433-439.

32. Buton, L. D., Fadmi, F. R., \& Mulyani, S. (2018). The Relation between Knowledge, Stress and Salt Consumption with Incidence of Hypertension in Elderly Woman Out Patients in General Hospital of Bahteramas Southeast Sulwesi Province. Indian Journal of Public Health Research \& Development, 9(6), 385-389. 